\title{
Mezun Görüşleri Bakımından Engellilerde Egzersiz ve Spor Eğitimi Bölümünün Profili"
}

\section{Profile of Department of the Exercise and Sports Education for Disabilities in}

\author{
Terms of Graduate Views
}

\section{ORIJIINAL ARAŞTIRMA/ \\ ORIGINAL RESEARCH}

\author{
Hasan Ceyhun $\mathrm{CAN}^{1 \dagger}$, \\ Ekrem Levent İLHAN ${ }^{2}$
}

${ }^{1}$ İstanbul-Cerrahpaşa Üniversitesi, İstanbul https://orcid.org/0000-0001-7000-9172

${ }^{2}$ Gazi Üniversitesi, Ankara

https://orcid.org/0000-0002-1117-2700
$\ddot{O} \mathbf{z}$

$\mathrm{Bu}$ araştırma, ülkemizde yeni açılmış bir bölüm olan Engellilerde Egzersiz ve Spor Eğitimi bölümden mezun olan öğrencilerin görüşleri bakımından bölümün profilinin incelenmesini amaçlamıştır. Bu amaçla çalışma nitel araştırma yaklaşımlarından olgubilim deseniyle tasarlanmıştır. Araştırma grubu, İnönü Üniversitesi Spor Bilimleri Fakültesi Engellilerde Egzersiz ve Spor Eğitimi bölümünde lisans eğitimi almış olan on iki öğrenciden oluşmaktadır. Araştırma grubunun belirlenmesinde amaçlı örneklem yöntemlerinden kartopu örnekleme yöntemi kullanılmıştır. Veri toplama aracı olarak yarı yapılandırılmış görüşme formu kullanılmış ve elde edilen veriler içerik analiziyle değerlendirilmiştir. Araştırmanın sonucunda bu bölümde lisans eğitimi almış ve mezun olmuş öğrencilerin çoğunluğuna bakıldığında, gerekli araştırmaları yaparak istihdam amaçlı bu bölümde eğitim almayı tercih ettikleri fakat eğitime başladıktan sonra bölüm değișikliği düşündükleri ve lisans eğitimleri boyunca aldıkları derslerin kalitesiz olduğu belirlenmiştir. Ayrıca katılımcıların engellilere yönelik olan tutumlarının, aldıkları eğitimle birlikte pozitif yönde değișimler gösterdiği ve engelli öğrencilere ayrılan kontenjanın artırılması gerekliliği bulgusu elde edilmiştir. Bir diğer bulgu olaraksa, Engellilerde Egzersiz ve Spor Eğitimi bölümünün özel eğitim bölümlerinden farklı olduğunu ve bölüm mezunlarının özel gereksinimli bireylerin bulunduğu kurumlarda spor eğitimi amaçlı istihdam edilmeleri gerekliliği belirlenmiştir. Buna ek olarak bölümün, alana hâkim uzmanlar yetiştirilmesi, engellilere kaliteli eğitim verilebilmesi, engellilere ve yakınlarına destek olunması ve engelli sporcular için gerekli olduğu tespit edilmiştir.

Anahtar Kelimeler: Engellilerde egzersiz, spor, eğitim

\begin{abstract}
This study aims to examine the profile of Department of The Exercise and Sports Education for Disabilities in Terms of Graduate Views, which is a new department in our country. Therefore, this study is designed with phenomenological pattern which is one of the qualitative research approaches. The study group of the research consists of twelve students who have graduated from the Department of The Exercise and Sports Education for Disabilities, Faculty of Sport Science, İnönü University. Snowball sampling method, which is one of the purposeful sampling methods, was used to determine the research group. As the data collection tool semi-structured interview form was used and the data obtained were evaluated by content analysis. As a result of this study, when the majority of the students who have graduated from this department were examined, it can be determined that they preferred to study in this department for employment purposes but after starting the classes they realized that the courses they took during their undergraduate education were of poor quality and even considered department change. Moreover, it was found that attitudes of the participants towards disabled people showed positive changes with the education they received and the quota for disabled students should be increased. Also as another finding, it is concluded that the Department of The Exercise and Sports Education for Disabilities is different from the special education departments and the graduates of this department should be employed in institutions with special needs for sports education. In addition to that, it is determined that it is vital to train experts in the field, to provide quality education to the disabled, to support the disabled and their relatives and to the disabled athletes.
\end{abstract}

Keywords: Exercise for disabilities, sport, education

\footnotetext{
*Bu çalışma 2-6 Ekim 2019 tarihleri arasında Ankara'da düzenlenen 5th International Eurasian Congress on 'Natural Nutrition, Healthy Life \& Sport' Kongresi’nde sözel bildiri olarak sunulmuştur.

† Sorumlu yazar: Hasan Ceyhun CAN, ceyhuncan@istanbul.edu.tr
} 


\section{GíRiş}

Toplumun her kademesinde farklılık oluşturacak sinıflar mevcuttur. Bu sinıflardan birisini de engelli bireyler oluşturmaktadır. Bu sınıfı oluşturan bireylerin, farklılıklarını en aza indirgeyebilecekleri ve potansiyellerini ortaya koyabilecekleri araç, spor olabilir (Kabasakal, 2007). Çünkü bireyler spor yolu ile çevresini daha iyi tanır, iletişimde bulunur ve kendilerine olan öz güvenlerini arttırırlar (Sevim, 2002). Sporun bireylerin oluşturduğu ortak yaşama sunmuş olduğu çeşitli katkılar vardır. Bu katkılar özellikli uzmanlık gereksinimini açığa çıkartmaktadır. Özel uzmanlık gerektiren alanların başında, okul içi ve dışı sportif etkinlikleri, engel tür ve düzeylerine göre düzenleyebilecek kalifiye eleman sorunu yaşayan ve nüfusun yaklaşık \%12'sini oluşturan toplumun engelli kesimi gelmektedir (Konar ve Yıldıran, 2012).

Engelli bireylerin toplumların ayrılmaz bir parçası olması durumu, insanlık tarihinin başlangıcından günümüze daha çok artış göstererek, modern çağ içerisinde anlam bulmuştur. Özellikle gelişmiş olan ülkeler, toplumunu oluşturan vatandaşları arasında ayrım gözetmeksizin tüm fertlerden kendisine en faydalı olacak şekilde yararlanmak amacındadırlar. $\mathrm{Bu}$ uğurda ülkeler, özel gereksinimli bireyleri topluma adapte edecek ve daha iyi bir şekilde hayatlarını sürdürmelerini sağlayacak olan girişimlerde bulunmaktadırlar. Bu girişimlerin başında ise eğitim gelmektedir.

Özel eğitime gereksinim duyan bireylerin, yaşamlarının her kesitinde hangi koşulda olurlarsa olsunlar, temel hakları olan eğitim hizmetinden yararlanmaları sağlanmalıdır. Ülkeler, özel gereksinim duyan vatandaşlarının eğitimleri adına ''uygun eğitim' yapılanması ortaya koymalıdırlar (Eroğlu, 2017). Beden Eğitimi ve Spor, özel gereksinim duyan vatandaşların alacakları uygun eğitimleri esnasında, sporun faydaları düşünüldüğünde, bireysel ve toplumsal uyum noktasında önem arz etmektedir (Koparan, 2013). Engelli bireylerin iyileştirilebilmeleri, uyumları ve yaşam standartlarının arttırılması, her türlü engel çeşitliliğine yönelik sportif faaliyet gösterebilecek kalifiyeli elemanlar aracılığıyla gerçekleştirilebilir. Bu sebeple, kendi içerisinde büyük farklılıklar gösteren engelli toplumu göz önüne alındığında, engelli bireyler için spor elemanı yetiştirecek yükseköğrenim programı açılması gereklilik göstermektedir (Konar ve Yildiran, 2012).

Ülkemizde belirli bir alanda eğitim vermek ve mezunlarını istihdam edebilmek üzere açılmış olan 'Engellilerde Egzersiz ve Spor Eğitimi', bölümü hakkında ulusal alanyazın 
taraması yapıldığında çok az sayıda araştırma olduğu dikkat çekmektedir (Arslan, 2014; Açak, Karakaya, Tan, Coşkuner, 2016; Vural, Esentaş ve Işıkgöz, 2016). Yapılan çalışmalar arasında bölümden mezun olan öğrencilerin görüşlerini veya okulun genel yapısını incelemeye yönelik bir araştırmaya rastlanılmamıştır.

$\mathrm{Bu}$ araştırma, mezun öğrenci görüşleri ışığında bölümün irdelenmesini ve elde edilen verilerin konu üzerinde yapılacak yeni çalışmalara ışık tutmasını amaçlamıştır.

\section{YÖNTEM}

\section{Çalışma Grubu}

Araştırmanın çalışma grubu, ülkemizde bu alanda mezun veren tek okul durumunda olmasından ötürü İnönü Üniversitesi, Engellilerde Egzersiz ve Spor Eğitimi Bölümü’nde eğitim görmüş olan öğrencilerle sınırlandırılmıştır. Araştırma grubu, amaçlı örnekleme yöntemlerinden kartopu örnekleme yöntemiyle belirlenmiştir. Yıldırım ve Şimşek (2016), bu yaklaşımı ' 'araştırmacının problemine ilişkin olarak zengin bilgi kaynağı olabilecek birey veya durumların saptanmasında özellikle etkilidir’' diye tanımlamıştır. Kartopu örneklemede öncelikle evrene ait birimlerden birisi ile temas kurulur. Temas kurulan birimin yardımıla ikinci birime, ikinci birimin yardımıyla üçüncü birime gidilir. $\mathrm{Bu}$ şekilde, sanki bir kartopunun büyümesi gibi örneklem büyüklüğü genişler (Yazıcıŏglu ve Erdoğan, 2004). Araştırma kapsamında toplamda 20 mezun öğrenci ile görüşülmüştür. Yeterli içerik oluşturmadığına kanaat getirilen görüşme formları değerlendirme dışında bırakılarak, verilerin doygunluğuna ulaştığı düşünülen 12 katılımcı ile yapılan görüşmeler değerlendirmeye tabi tutulmuştur.

Tablo 1. Kat1lımciların demografik bilgileri

\begin{tabular}{lcccl}
\hline Katılımcılar & Yaş & Cinsiyet & Mezuniyet Yılı & Mevcut Durumu \\
\hline K1 & 26 & $\mathrm{~K}$ & 2017 & Lisansüstü Öğrencisi* \\
K2 & 23 & $\mathrm{E}$ & 2018 & Antrenör \\
K3 & 23 & $\mathrm{E}$ & 2018 & Çalışmıyor \\
K4 & 26 & $\mathrm{~K}$ & 2017 & KPSS'ye hazırlanıyor \\
K5 & 25 & $\mathrm{~K}$ & 2017 & Antrenör \\
K6 & 26 & $\mathrm{~K}$ & 2017 & KPSS'ye hazırlanıyor \\
K7 & 24 & $\mathrm{~K}$ & 2017 & Antrenör \\
K8 & 24 & $\mathrm{~K}$ & 2017 & Öğretmen \\
K9 & 26 & $\mathrm{~K}$ & 2016 & Çalışmı̈yor \\
K10 & 25 & $\mathrm{~K}$ & 2017 & Lisansüstü Öğrencisi* \\
K11 & 25 & $\mathrm{E}$ & 2017 & Ŏğretmen*** \\
K12 & 27 & $\mathrm{E}$ & 2017 & KPSS'ye hazırlanıyor \\
\hline *Engelliler ve Spor alanında eğitim gördüklerini belirtmişlerdir. ** Özel eğitim alanında öğretmenlik yaptı̆̆ın belirtmektedir.
\end{tabular}




\section{Veri Toplama Aracı}

Araştırmada yarı yapılandırılmış görüşme tekniği kullanılmıştır. Yarı yapılandırılmış görüşme katılımcıya önceden belirlenmiş görüşme planının aynen uygulandığı, bunun yanında yeni soruların sorulabildiği esnek görüşmelerdir (Karasar, 2015).

Veri toplama araçlarının oluşturulması aşamasında, araştırmanın odak noktası olan bölüm ve ilgilendiği alan hakkında ilgili alanyazın taranarak öncelikle taslak formlar hazırlanmıştır. $\mathrm{Bu}$ formlar, üç alan uzmanının görüşleri akabinde düzenlenip son halini almıştır. Görüşmeler çevrimiçi ortamda gerçekleştirilmiştir. Mülakat içeriğinde, demografik sorular dişında 10 adet soruya yer verilmiştir. Mülakat sorularından bazıları şu şekildedir:

- $\quad$ Bu bölümde eğitim almayı neden tercih ettiniz?

- $\quad$ Bölüme başlamadan önceki engellilere yönelik bakış açınız ile mezun olduktan sonraki engellilere bakış açınız arasında ne gibi farklılıklar oldu?

- $\quad \mathrm{Bu}$ bölüm mezunlarının nerelerde istihdam edilmeleri gerektiğini düşünüyorsunuz?

\section{Verilerin Analizi}

Elde edilen veriler 'İçerik Analizi', yöntemi ile analiz edilmiştir. İçerik analizinde temel amaç, toplanan verileri açıklayabilecek kavramlara ve ilişkilere ulaşmaktır. Bu amaçla toplanan verilerin önce kavramsallaştırılması, daha sonra da ortaya çıkan kavramlara göre mantıklı bir biçimde düzenlenmesi ve buna göre veriyi açıklayan temaların saptanması gerekmektedir (Yıldırım ve Şimşek, 2016).

$\mathrm{Bu}$ çalışmada, yapılan analizler neticesinde kodlara ulaşılmış bu kodlar kategorize edildikten sonra temalar altında toplanmıştır. Bununla birlikte, toplanan veriler frekanslarına göre sıralanarak tablo oluşturulmuştur. Ayrıca, görüşmeye katılım sağlayan kişiler ' $\mathrm{K}$ ' şeklinde numaralandırılarak kodlanmıştır. 


\section{BULGULAR}

Engellilerde Egzersiz ve Spor Eğitimi Bölümü mezun görüşlerini belirlemek için yapılan görüşmeler neticesinde elde edilen verilerin içerik analizine tabi tutulmasıyla; '’lisans eğitimi', ‘'engelli tutumları", ve '’bölüm gerekliliği', olmak üzere üç ana tema ortaya çıkmıştır. Her bir tema bünyesindeki alt temalar ve bu alt temalara ilişkin kodlar aşağıda açıklanmıştır.

Tablo 2. Katılımcıların lisans eğitimine ilişkin tema, alt temalar ve kodlar

\begin{tabular}{|c|c|c|c|c|c|}
\hline Tema & Alt Temalar & Kodlar & & Katılımcı & $\mathrm{f}$ \\
\hline \multirow{12}{*}{ 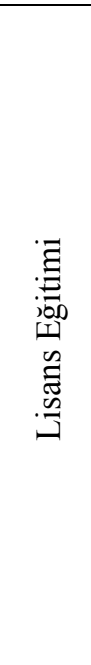 } & \multirow{3}{*}{$\begin{array}{l}\text { Eğitim almak } \\
\text { isteme sebepleri }\end{array}$} & \multicolumn{2}{|c|}{ İstihdam olanakları } & $\mathrm{K} 1, \mathrm{~K} 2, \mathrm{~K} 3, \mathrm{~K} 4, \mathrm{~K} 5, \mathrm{~K} 8, \mathrm{~K} 12$ & 7 \\
\hline & & \multicolumn{2}{|c|}{ Bölüme özgü özellikler } & $\mathrm{K} 3, \mathrm{~K} 7, \mathrm{~K} 9, \mathrm{~K} 10$ & 4 \\
\hline & & \multicolumn{2}{|c|}{ Engellilerle çalışma isteği } & $\mathrm{K} 4, \mathrm{~K} 6, \mathrm{~K} 10, \mathrm{~K} 11$ & 4 \\
\hline & \multirow{3}{*}{$\begin{array}{l}\text { Bölümle ilgili bilgi } \\
\text { sahibi olma durumu }\end{array}$} & \multirow{3}{*}{$\begin{array}{l}\text { Bilgisi vardı } \\
\text { Bilgisi yoktu }\end{array}$} & Yakınlardan bilgi alma & $\mathrm{K} 1, \mathrm{~K} 2, \mathrm{~K} 3$ & \multirow{2}{*}{10} \\
\hline & & & \multirow[t]{2}{*}{ Kişisel çabalarla edinme } & $\mathrm{K} 1, \mathrm{~K} 3, \mathrm{~K} 7, \mathrm{~K} 8, \mathrm{~K} 9, \mathrm{~K} 10, \mathrm{~K} 11$ & \\
\hline & & & & K4,K5,K6,K12 & 4 \\
\hline & \multirow{2}{*}{$\begin{array}{l}\text { Bölüm değişikliği } \\
\text { düşünme durumu }\end{array}$} & Düşündüm & $\begin{array}{l}\text { Bölümle ilgili sorunlar } \\
\text { Kişisel sorunlar }\end{array}$ & $\begin{array}{l}\mathrm{K} 1, \mathrm{~K} 2, \mathrm{~K} 3, \mathrm{~K} 4, \mathrm{~K} 7, \mathrm{~K} 12 \\
\mathrm{~K} 4, \mathrm{~K} 5\end{array}$ & 8 \\
\hline & & \multicolumn{2}{|l|}{ Düşünmedim } & $\mathrm{K} 6, \mathrm{~K} 8, \mathrm{~K} 9, \mathrm{~K} 10, \mathrm{~K} 11$ & 5 \\
\hline & \multirow{4}{*}{$\begin{array}{l}\text { Lisans eğitimin } \\
\text { kalite durumu }\end{array}$} & Kaliteliydi & Multidisipliner ders almak & $\begin{array}{l}\mathrm{K} 1, \mathrm{~K} 4 \\
\mathrm{~K} 1 \mathrm{~K} 4 \mathrm{~K} 5 \mathrm{~K} 9\end{array}$ & 6 \\
\hline & & \multirow{3}{*}{$\begin{array}{l}\text { Kaliteli } \\
\text { değildi }\end{array}$} & Alan dersleri yetersizliği & $\mathrm{K} 2, \mathrm{~K} 3, \mathrm{~K} 5, \mathrm{~K} 7, \mathrm{~K} 12$ & \multirow{3}{*}{10} \\
\hline & & & Akademisyenlerin yetersizliği & K6, K10 & \\
\hline & & & Bölümün yeni kurulmuş oluşu & $\mathrm{K} 8, \mathrm{~K} 10, \mathrm{~K} 11$ & \\
\hline
\end{tabular}

Katılımcıların lisans eğitimine ilişkin görüşleri incelendiğinde ortaya dört alt tema çıkmıştır. İlk alt tema olan '"eğitim almak isteme sebepleri', alt teması altında bazı katılımcıların görüşlerine aşağıda yer verilmiştir.

K3: '’...Türkiye'de bir ilk teşkil etmesi ve ilerleyen zamanlarda iş bulma imkânlarının fazla olabileceği, İngilizce hazırlık okutulması, ayrıca da ilgi alanım olan spor ile alakalı bir bölüm olması dolayısıyla seçtim. ,

K4: '...̈̈ncelikli amacım istihdam konusunda sorun yaşamamakt. Daha sonra bu bireylerle çalışmak onları yakından tanımak onlara yardımcı olmak için ve engellilere olan bakış açımın değişmesi için seçtim...,

İkinci alt tema olan 'bölümle ilgili bilgi sahibi olma durumu', alt temasına ilişkin katılımcıların görüşlerinden bazıları şu şekildedir:

K5: 'Herhangi bir araştırma yapmadım.",

K9: '...Dersler, eğitim süresi, eğitimin içeriği ve istihdam alanları gibi konuları araştırdım..., 
Üçüncü alt tema olan ''bölüm değişikliği düşünme durumu', alt temasına ilişkin katılımcıların görüşlerinden bazıları şu şekildedir:

K1: 'Çoğu zaman evet düşündüm. Bunun birçok nedeni var. Bölüm açıldı̆̆ı zaman 1 yıl zorunlu İnilizce hazırlık ĕgitimi aldık. Bizim bir alt dönemden sonra bu zorunluluk kaldırıldı. Bu bana tutarsız geldi. Dört yıl stajımız vardı. Ama stajlarda çok kalabalıktık. Bu nedenle yeterli verimi alamadığımı düşündüğümde bırakmak istedim. Bölüme gelirken M.E.B. 'de ayrı bir atamamız olacă̆ı söylendi (yani engelli okullarına sadece bizim bölümün mezunlarının atanacă̆ı, bunun olamayacă̆ını sonradan öğrendikten sonra). Pedagolojik formasyon derslerinin hepsini formal öğretim yılımızda almamıza ră̆men 'Beden Eğitimi Öğretmeni”' olarak atanamayacă̆ımız konuşulmuştu. Bu nedenle bırakmak istedim. ',

K4: '...Yakın çevremde engelli kimse yoktu. Bölüme, bölüme başladıktan sonra bu bireylerle içli dışlı olmaya başladım. Daha hazırlık yıllarında hiçbir eğitim ve tecrübem yokken direk engelli bireylerle çalışmalarımız oldu. Bu bireyler için yapılan çalışmalarda yanımda deneyimli kimse olmadığından tek başıma ilgilenmek zorunda kaldım. Tabi ilk başlarda "deli cesareti" diyelim. Onlarla ilgilenme, onlara yarımcı olma, onlara bir şeyler kattı̆̆ımı düşünme duygusu bana hoş geliyordu. İlk etapta yapabileceğimi düşünmüşı̈̈m... Sonra ki aktivitelerde daha ă̆ır engelli bireylerle çalıştı̆̆ımda yapamayacă̆ımı düşündüm. Ve bölüm Malatya'da yeni açılan bir bölüm olduğundan müfredat programında bazı eksiklikten dolayı biraz sıkıntı yaşadık. Bunlardan dolayı bölüm değiştirmeyi düşündüm. ,'

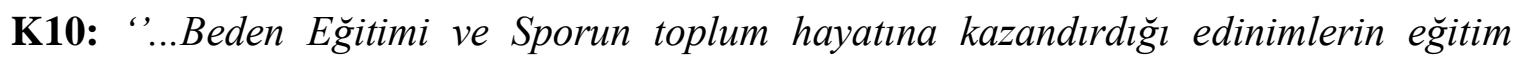
sürecinde gördükçe, özel uzmanlık gerektiren alanların ihtiyacını ve bunları karşılayabilecek spor uzmanlarının yetiştirilmesi gerektiğini açıkça görmekteyim. Bu yüzden bölümümü değiştirmekten ziyade bu alan daha fazla ne yapabilirdim diye düşünerek yıllarca engelli ve spor alanında çalışma yaptım ve kaldım...",

Katılımcıların lisans eğitimlerine ilişkin ortaya çıkan dördüncü alt tema 'lisans eğitiminin kalite durumu' dur. Bu alt temaya ilişkin bazı katılımcı görüşlerine şu şekildedir:

K1: 'Evet. Almış olduğum eğitimin kaliteli olduğun düşünüyorum. Tek bir engel grubuna değil tüm engel gruplarına özel ayr ayrı dersler aldık. Hem pedagojik formasyon 
dersleri, hem engelliler hakkında dersler hem de beden eğitimiyle ilgili dersler aldlk. Dönemlik 11-12 ders aldı̆̆ımız zamanlar oldu..."

K2: '.... Lisans eğitimi süresince aldı̆̆ımız eğitim keşke iyi diyebilseydim maalesef yeterli düzeyde değildi. Bizler engellilerde spor eğitmeni gibi değil de bakıcı gibi yetişstirilmeye çalışıldık..."

K8: '....Bölümün yeni olması itibariyle çok kaliteli bir eğitim alamadık. Daha sistemli bir program dâhilinde lisans eğitimini tamamlayabilirdik..."

Tablo 3. Katılımcıların engelli bireylere yönelik tutumlarına ilişkin tema, alt temalar ve kodlar

\begin{tabular}{|c|c|c|c|c|c|}
\hline Tema & Alt Temalar & Kodlar & & Katılımcı & $\mathrm{f}$ \\
\hline \multirow{6}{*}{ 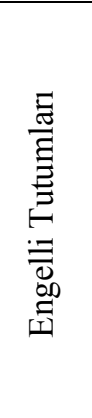 } & \multirow{4}{*}{$\begin{array}{l}\text { Engelli } \\
\text { Bakış Açıı } \\
\text { Değişimi }\end{array}$} & \multirow{3}{*}{ Pozitif } & Empati Yapmayı Öğrenmek & $\mathrm{K} 1, \mathrm{~K} 4$ & \multirow{3}{*}{11} \\
\hline & & & $\begin{array}{l}\text { Engellilerin Başarılı } \\
\text { Olabilecekleri Düşüncesi }\end{array}$ & $\mathrm{K} 1, \mathrm{~K} 2, \mathrm{~K} 8$ & \\
\hline & & & $\begin{array}{l}\text { Engelliler Hakkında Detaylı } \\
\text { Bilgi Edinmek }\end{array}$ & $\mathrm{K} 1, \mathrm{~K} 3, \mathrm{~K} 4, \mathrm{~K} 8, \mathrm{~K} 9, \mathrm{~K} 10$ & \\
\hline & & Negatif & $\begin{array}{l}\text { Bölüm Öncesinde Yeterli Bilgi } \\
\text { Hayal Kırıklığı Yaşama }\end{array}$ & $\begin{array}{l}\mathrm{K} 6, \mathrm{~K} 11 \\
\mathrm{~K} 5, \mathrm{~K} 7, \mathrm{~K} 12\end{array}$ & 5 \\
\hline & Engelli & \multirow{2}{*}{\multicolumn{2}{|c|}{$\begin{array}{l}\text { Arttırılmalı } \\
\text { Arttırılmamalı }\end{array}$}} & $\mathrm{K} 1, \mathrm{~K} 3, \mathrm{~K} 4, \mathrm{~K} 6, \mathrm{~K} 7, \mathrm{~K} 8, \mathrm{~K} 10, \mathrm{~K} 11$ & 8 \\
\hline & Kontenjanı & & & K2,K5,K9,K12 & 4 \\
\hline
\end{tabular}

Katılımcıların engelli bireylere yönelik tutumlarına ilişkin görüşleri incelendiğinde, ortaya iki alt tema çıkmıştır. İlk alt tema “engelli bakış açısı değişimi”” dir. Bu alt tema altında bazı katılımcıların görüşlerine aşağıda yer verilmiştir.

K1: '....Bölüme başladıktan sonra tamamen dünyalarına girme firsatım oldu. Örneğin: Görme engellilerde spor dersinde 'goalball"' oynarken gözlerimizi bantladık ve onların neler hissettiğini anlayabildim. Neleri bizim kadar iyi yapabildiklerini görme firsatımda stajlar sayesinde oldu. Firsat tanındı̆̆ında çok başarılı olabileceklerini anlamış oldum..."

K8: ' ...Bölüme başlamadan önce engelliler hakkinda pek bilgiye sahip değildim. Sadece toplumdan soyutlanmış ve yardıma ihtiyacı olan bireyler olduklarını düşünüp, üzülüyordum. Bölümü okuduktan sonra onları hayata kazandıracak kişilerin bizler olduğunu ve onlarında özel gereksinime ihtiyacı olmayan bireyler gibi toplumda yer almaları gerektiğini fark ettim. Yeterli destekle kendilerine ve topluma faydalı mutlu bireyler olabileceklerini gördüm..." 
K12: '...Baş̧lamadan çok iyimser düşünüyordum. Başladıktan sonra engelli bireylerin reklam aracından başka bir şey için kullanılmadıklarını gördüm. Onlara karşı daha duygusal bir bakış oluştu diyebilirim..."

İkinci alt tema olan 'engelli kontenjanı" alt temasına ilişkin katılımcıların görüşlerinden bazıları şu şekildedir:

K3: '...Sayı arttırılarak engelli bireylerin normal bireylerle kaynaşmast sağlanabilir. Ayrıca sayı az olan bir ortamda engelliler rahatça dışlanabilirken, eğer sayı fazla olursa dışlanma olmaz diye düşünmekteyim. Bu yüzdende sayı arttırlabilir."

K5: '....Kontenjanı neye dayanarak bu şekilde yaptılar bilmiyorum ama bence güzel bir dağılım...,

K6: '...Engel derecesine göre kontenjanı arttırabilirler artmast gerekir...",

K11: '....Her şeyden önce eşitlik ilkesine aykır bulurum. Diğer bölümlerdeki engelli kontenjanı ile eşitlenmesi gerektiğini düşünüyorum. Kendi engel grupları dışındaki engellilerle çok iyi anlaşabileceklerini ve faydalı olacaklarını düşünüyorum. Bu yüzden kontenjanın artması gerektiğini düşünüyorum.',

Tablo 4. Katılımcıların bölüm gerekliliği görüşlerine yönelik tema, alt temalar ve kodlar

\begin{tabular}{|c|c|c|c|c|}
\hline Tema & Alt Temalar & Kodlar & Kat1lımc1 & $\mathrm{f}$ \\
\hline \multirow{13}{*}{ 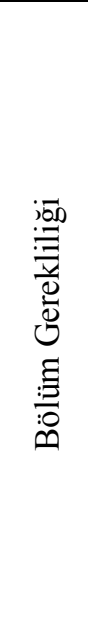 } & \multirow{2}{*}{$\begin{array}{l}\text { Özel eğitim } \\
\text { Bölümünden fark1 }\end{array}$} & Spor temelli uygulama dersleri & $\mathrm{K} 2, \mathrm{~K} 3, \mathrm{~K} 4, \mathrm{~K} 5, \mathrm{~K} 7, \mathrm{~K} 8, \mathrm{~K} 10, \mathrm{~K} 11$ & 8 \\
\hline & & Engellileri bir bütün olarak ele alması* & $\mathrm{K} 1, \mathrm{~K} 5, \mathrm{~K} 6, \mathrm{~K} 9, \mathrm{~K} 10, \mathrm{~K} 12$ & 6 \\
\hline & \multirow{7}{*}{$\begin{array}{l}\text { İstihdam edilme } \\
\text { alanları }\end{array}$} & MEB'e bağlı kuruluşlar & $\mathrm{K} 1, \mathrm{~K} 3, \mathrm{~K} 4, \mathrm{~K} 5$ & 4 \\
\hline & & Rehabilitasyon merkezleri & $\mathrm{K} 1, \mathrm{~K} 5, \mathrm{~K} 6, \mathrm{~K} 8, \mathrm{~K} 9$ & 5 \\
\hline & & GSB kadrosu & $\mathrm{K} 1, \mathrm{~K} 3, \mathrm{~K} 4, \mathrm{~K} 5, \mathrm{~K} 11$ & 5 \\
\hline & & Belediye spor merkezleri & $\mathrm{K} 1, \mathrm{~K} 9, \mathrm{~K} 12$ & 3 \\
\hline & & Antrenörlük & $\mathrm{K} 2, \mathrm{~K} 7, \mathrm{~K} 9$ & 3 \\
\hline & & Özel eğitim kurumları & $\mathrm{K} 3, \mathrm{~K} 6, \mathrm{~K} 8, \mathrm{~K} 9, \mathrm{~K} 10, \mathrm{~K} 11, \mathrm{~K} 12$ & 7 \\
\hline & & Kaynaştırma eğitimi veren kurumlar & K9,K10 & 2 \\
\hline & \multirow{4}{*}{$\begin{array}{l}\text { Bölüme ihtiyaç } \\
\text { Duyulma durumu }\end{array}$} & Engellilere kaliteli eğitim verilmesi & $\mathrm{K} 5, \mathrm{~K} 6, \mathrm{~K} 8, \mathrm{~K} 9, \mathrm{~K} 10, \mathrm{~K} 11$ & 6 \\
\hline & & Engelli sporcular için & $\mathrm{K} 1, \mathrm{~K} 2, \mathrm{~K} 3, \mathrm{~K} 10, \mathrm{~K} 12$ & 5 \\
\hline & & Alana hakim uzmanlar yetiştirilmesi & $\mathrm{K} 3, \mathrm{~K} 4, \mathrm{~K} 5, \mathrm{~K} 6, \mathrm{~K} 7, \mathrm{~K} 8, \mathrm{~K} 9, \mathrm{~K} 10, \mathrm{~K} 11$ & 9 \\
\hline & & Engellilere ve yakınlarına destek olunmasi & $\mathrm{K} 1, \mathrm{~K} 4, \mathrm{~K} 7, \mathrm{~K} 12$ & 4 \\
\hline
\end{tabular}

*Bahsedilen, engelliler hakkında bilişsel, duyusal ve devinişsel olarak bir bütün halinde eğitim alınmasıdır.

Katılımcıların bölüm gerekliliği görüşlerine yönelik görüşleri incelendiğinde, üç alt tema tanımlanmıştır. Bunlardan ilki 'özel eğitim bölümünden farkı" alt temasıdır. Bu alt temaya ait, katılımcıların bazı görüşlerine aşağıda yer verilmiştir. 
K5: '...Özel eğitim bölümlerinden farklı olduğunu şu yönde düşünüyorum: daha çok sporsal faaliyet ve eğitsel oyun katarak etkinliklerde bireylerin grupla/ bireysel gelişimine katkı sağlamaktadır. Özel eğitimde psikomotor becerilerin daha sinırlı geliştirildiği daha çok bilişsel ögrenmelere katkn sağllyor. Engellilerde egzersiz ve spor eğitimi bölümünün eğitimi, bireyleri çok yönlü gelişstirecek şekilde çalışma programı hazırlanmış fakat hayata geçirmekte sıkıntı yaşadı̆̆ın düşünüyorum.',

K9: 'Tabi ki farklar var. Bunun en büyük sebebi de bizim sadece sinıf ortamina bağgl kalmamamız diye düşünüyorum. Başta insan anatomisini öğrenmeyle başlayan ve engelli bireyler için tamamen doğru bir eğitimin verilmesi için devam edilen bütün engel gruplarının nedenleri, sonuçları, yapılması ve yapılmaması gerekenleri öğrenerek yola başlyyoruz. Bu farkların bir kaçını şöyle siralayabiliriz; Diğer bölümlerde genel olarak zihinsel açıdan neyin nasıl öğretileceğine odaklanllırken biz de kişinin Bedensel, Zihinsel, Psikolojik bütünlügüüle birlikte başarlya ulaşması söz konusu. Bazı bölümlerde engellinin sadece çallşmayan tarafina yönelinirken biz de tam tersi... ",

K12: '...Bizim bölüm daha çok devinişsel olanla ilgili olduğu için özel eğitim bölümünden ayrllır..."

İkinci alt tema olan "istihdam edilme alanları" alt temasına ilişkin katılımcıların görüşlerinden bazıları şu şekildedir:

K1: 'Milli Ĕgitim Bakanlı̆ğ'na bağll tüm engelliler okullarında 'beden eğitimi ögretmeni" olarak, Rehabilitasyon merkezlerine 'zorunluluk' getirilerek bu merkezlerde (çünkü zorunluluk olmadığından hiçbir rehabilitasyon merkezi ekstra bir ögretmene fazla para vermemek adına beden eğitimi öğretmeni çalıştırmamaktadır), belediyenin engelliler için açtı̆̆ı spor merkezlerinde, Gençlik Spor Bakanlığı' nın ayrı bir alımla "engelliler için spor uzmanı" şeklinde kadro açmasılyla..."

K7: 'Engelli spor federasyonlarında ve kulüplerinde, antrenör bilgilendirmelerde, engelli okullarında, açılacak olan bölümlerde yer almalıdır."

K9: 'Engelli bireylerin olduğu bütün eğitim kurum ve kuruluşlarında. Örneğin; kaynaştırma eğitimi veren bütün okullar, rehabilitasyon merkezleri, hastanelerin rehabilitasyon merkezleri, spor federasyonları, engelsiz yaşam merkezleri vb.",

Katılımcıların bölüm gerekliliği görüşlerine ilişkin ortaya çıkan üçüncü alt tema "bölüme ihtiyaç duyulma durumu' dur. Bu alt temaya ilişkin bazı katılımcı görüşlerine şu şekildedir: 
K3: "...Ülkemizdeki hiçbir işin uzman kişilerce yapılmamasından dolayı hem normal spor branşları hem de engelli spor branşlarında başarı sağlanmamaktadır. Bu bölümün müfredat programı biraz daha gelişstirilerek Engelli bireylerin spora katılması ve profesyonelleştirilmesi sağlanırsa, bu bölüm gerçekten gerekli olabilir..."

K5: '...Bölümün gereksinimleri karşılaması gereken bireyler için bulunmaz bir firsat olduğınu düşünüyorum... Çünkü 4 yll boyunca stajlar, etkinlikler vs. bu bireyler ile yetiştirilen spor uzmanlarının ülkemizde daha verimli kendine güvenen bireyler yetiştireceğini düşünüyorum. Bölüm gerekli fakat görmezden geliniyor. Branşlaşma yoluna giderek her engel grubunda ayrı ayrı başarılara imza atılacă̆ına inaniyorum..."

K6: "...Gereklidir tabi engelliler hakkında daha çok bilgisi olan birisinin engellilerle çalışması daha uygundur. Normal beden eğitimi öğretmenleri engellilerin hangi rahatsızlıkları var ya da hangi antrenmanı yaptırması gerektiğini bilmeyip yanlı̧̧ uygulama yaptırırsa bu kişide rahatsızlı̆̆ını tetikler. Kesinlikle olması gereken bir bölümdür..."

K10: 'Engellilerde egzersiz ve spor eğitimi bölümü engelli bireylere spor yapma olanakları sağlamayı ve engellilerin sportif etkinliklerle rehabilite olması amactyla önem taşımaktadır. Her bireyin yetenek düzeyine, motivasyon, ilgi ve öğrenme stillerine uygun bir tarzda eğitim sağlanmaktadır. Özellikle ortalamadan daha yavaş gelişen çocuklar için bu husus önem arz etmektedir..."

K11: 'Bu bölüm engelli bireyler için şart. Engelli çocuklarımızın beden eğitiminde ögrendikleri bana göre eğitimlerinin \%50 sini oluşturuyor. Bu yüzden eğer beden eğitimi derslerini bizim bölüm mezunları girerse çok daha faydalı olacağını düşünüyorum ...",

K12: '...Bölümün gerekliliği tartışllmaz. Bölüm Ankara-İstanbul gibi üniversitelerinde açılsaydl şimdiye kadar gerekli değeri görmüş̧̈ü. Engelli bireylerin sporla uğraşmalar hem bizi hem ailelerini mutlu ediyor..."

\section{TARTIŞMA VE SONUÇ}

Bu araştırmada, ülkemizde yeni bir bölüm olan ''Engellilerde Egzersiz ve Spor Eğitimi'” bölümünün mezunlarının görüşleri tespit edilmiştir. Katılımcıların görüşleri ' lisans eğitimi', ‘'engelli tutumları"' ve 'bölüm gerekliliği'” olmak üzere üç ana tema altında incelenmiştir. 
Katılımcıların demografik özellikleri incelendiğinde, toplam 12 katılımcının 4 erkek, 8 kadın olmak üzere dağılım sergilediği görülmektedir. Katılımcıların yaş ortalamaları 25'tir. Mezuniyet durumlarına bakıldığında 2017 yılı mezun öğrencilerinin yoğunlukta olduğu görülmektedir. Mevcut durumlarına bakıldığında ise, 12 katılımcıdan yalnızca 3 tanesinin (\%25) alanıyla alakalı bir işle meşgul olduğu göze çarpmaktadır.

Araştırmada lisans eğitimi temasında elde edilen verilere göre, katılımcıların eğitim almak isteme sebepleri incelendiğinde istihdam olanakları öne çıkmaktadır. Ayrıca bölüme özgü özellikler ve engellilerle çalışma isteği diğer tercih sebepleridir. Mülakatlardan elde edilen bilgilere göre katılımcılarda, yeni ve öncü bir bölüm olmasından ötürü iş imkânlarının yüksek olacağı inanci mevcuttur.

Katılımcıların büyük bir kısmının bölümü tercih etmeden önce araştırma yapmış olduğu görülmüştür. Buna rağmen, eğitimleri sürecince çoğunluğun bölümle ilgili sorunlar veya kişisel sorunları yüzünden bölüm değişikliğini düşündükleri görülmektedir. Lisans eğitiminin kalite durumu hakkında, katılımcıların çoğunluğu aldıkları eğitiminin kaliteli olmadığı görüşünü belirtmiştir. Sebep olarak; alan derslerinin yetersiz oluşu, akademisyenlerin yetersiz oluşları ve bölümün yeni kurulmuş olmasını göstermiş̧lerdir. Bölümle ilgili problemler hakkında mezunlar, bölümün lokasyonu, zorunlu İngilizce hazırlık sınıfının bulunması, bölüm tercih edildiğinde MEB atamasından ayrı atamalar olacağının vaat edilmesi, müfredatının eksikliği gibi konularda bölümün yeni oluşundan ötürü eksikliklerin var oluşuna vurgu yapmışlardır. Ayrıca staj imkânlarının yeterli sayıda olmaması ve stajlarda sayıca kalabalık olunmasından ötürü mezun öğrenciler, uygulamalardan verim alamadıklarını belirtmişlerdir. Bu durum, bölümün program yeterlilikleri ilkesinde belirtilen ''Engelli bireylere yönelik spor eğitimi, egzersiz ve beden eğitimi öğretimi alanlarıyla ilgili kavramları ve ilkeleri uygulama ortamına transfer eder, yerinde etkili şekilde kullanır, aralarındaki ilişkiyi açıklama bilgisine sahiptir.' maddesinde belirtilmiş olan uygulama ortamına transfer etmesi durumuyla uyuşmamaktadır. $\mathrm{Bu}$ konuyla ilgili Avramidis, Bayliss ve Burden (2000) şu vurguyu yapmaktadır: '’̈̈ğretmen adaylarının engelli öğrencilerle bir araya gelerek öğretme deneyimi kazanmaları, özgüvenlerinin artması, korku ve kaygılarının azalması, engelli çocuklarla iletişim becerilerinin geliştirilmesi yönünden etkili olmaktadir',.

Mülakatlar esnasında katılımcılar, akademisyenlerin bölüm hakkında yeterli bilgiye sahip olmadıklarını, alandan gelen tecrübeli kişilerden ders almalarının kendi yararlarına olacaklarını 
da dile getirmişlerdir. Lisans eğitiminin yetersiz bulunuyor olması durumunun, bölüm misyonunda belirtilen '’ülkemizde ve bölgemizde bu alanda lisans ve lisansüstü eğitim veren en saygın eğitim kurumu olmayı hedeflemektedir’' ilkesiyle ters düştüğü söylenebilir. Ayrıca bölümün vizyonunda belirtilen Engellilerde Egzersiz ve Spor Eğitimi programının bireylerin '"mesleğinde yeterlilik kazanmış" olmasını hedefler ifadesi de karşılamadığı söylenebilir. Diğer taraftan, multidisipliner ders alınması ve ders içeriklerinin kaliteli olmasından ötürü bölümün vermiş olduğu lisans eğitiminin kaliteli olduğunu belirten katılımcılar da bulunmaktadır.

Engelli tutumları temasından elde edilen verilerde, katılımcıların lisans eğitimi aldıktan sonra yoğunluklu olarak engellilere yönelik tutumlarının pozitif yönde değişism sağladığı tespit edilmiştir. Katılımcılar, engellilere yönelik empati yapmayı öğrendikleri, engelliler hakkında detaylı bilgi edindikleri ve engellilerin başarılı olabileceklerini düşünmeleri yönünde almış oldukları eğitimle değişimler yaşadıklarını belirtmişlerdir. Pozitif yönde bakış açılarında değişim yaşayan katılımcılar, bölüme başlamadan evvel engelliler hakkında yeterli bilgi sahibi olmadıklarını ve onlara karşı acıma duygusu hissettiklerini aktarmışlardır. Fakat aldıkları eğitim ve engellilerle geçirmiş oldukları zaman sonrasında onlarında özel gereksinimi olmayan bireyler gibi toplumda rahatlıkla yer alabileceklerini belirtmişlerdir. Bölüme başlamadan önce, daha sonradan elde ettiği bilgilerin bir değişim yaratmayacağı düzeyde, bilgi seviyesine sahip olanların engellilere yönelik bakış açılarının değişiminin negatif olduğu görülmüştür. Ayrıca katılımcılar arasında, lisans eğitimi sonrasında engellilere yönelik hayal kırıklığı yaşadıklarından dolayı bakış açılarının negatif yönde değiştiğini belirtenlerde bulunmaktadır.

Katılımcıların, bölüme öğrenci alımında engellilere ayrılan kontenjanlar ile ilgili görüşleri incelendiğinde, çoğunluğun kontenjanların artırılması gerekliliğini vurguladığı görülmektedir. Katılımcılar engelli bireylerin benzer durumda olan bireylerle kolaylıkla empati kurup, anlaşabildiklerini ve onlara daha faydalı olabileceklerini belirtmişlerdir. Buna ek olarak engelli bireylerin sayısal olarak fazla oldukları ortamlarda daha rahat hissettiklerini aktarmışlardır. Engelliler ile engelli olmayan toplumun diğer kesimleri arasındaki ilişkiyi inceleyen araştırmalarda, engelli olmayan bireylerin engelli bireyler ile iletişime girmek istemediğini ortaya koymuştur (Yılmaz, Gökçe, Şavklı ve Çeşmeci, 2012). Türkiye'de ve Dünya'da yapılmış birçok çalışma ise, farklı kültürlerin engelli bireyleri çeşitli olumsuz kültürel etiketlemeler içinde değerlendirdiğini ortaya koymuştur. $\mathrm{Bu}$ etiketlemeler engelli bireyleri çevrelerinden 
uzaklaştırarak, yalnızlaşmalarına neden olmaktadır. Bu durum özgüven eksikliği, meslek edinememe ve en kötüsü intihar ile de sonuçlanabilmektedir (Burcu, 2013).

Bölüm gerekliliği teması altında katılımcıların tamamının eğitim aldıkları bölümün, özel eğitim bölümlerinden farklı olduklarını belirtmişlerdir. Bölümün farkının, spor temelli uygulama dersleri ve engellileri bir bütün olarak ele alması olarak iki farklı şekilde belirtmişlerdir. Engellilerde spor eğitimi verilirken başlıca şartlardan bir tanesi uygulamalı aktivitelerdir. Çünkü uygulamalı aktiviteler esnasında engelli birey daha verimli öğrenir (Arslan, 2014). Kınalı (2003) Beden Eğitimi ve Spor etkinlikleri için, 'Engelli bireylerin gerek engelleri dolayısıyla içinde bulundukları ruh hali ve gerekse toplumun kendilerine karşı olan tavırlarının doğal sonucu olarak ortaya çıkan saldırganlık, öfke ve kıskançlık gibi duygularını kontrol etmelerini sağlar'" demiştir. Engellilerde Egzersiz ve Spor Eğitimi bölümünün engellileri eğitmekte sporu temel almış olması onu diğer özel eğitim bölümlerinden ayıran en keskin özelliğidir.

Bölüm mezunlarının nerelerde istihdam edilmesi gerektiğine yönelik, katılımcılar çeşitli görüşler ortaya koymuşlardır. Katılımcıların belirlediği önem sırasına göre, istihdam sağlanabilecek alanlar şu şekildedir; özel eğitim kurumları, rehabilitasyon merkezleri, Gençlik ve Spor Bakanlığı kadrosu, Milli Eğitim Bakanlığı'na bağlı kuruluşlar, belediye spor merkezleri, antrenör ve kaynaştırma eğitimi veren kurumlar. Bahsi geçen bölümlerden anlaşılan ve mülakattan elde edilen bilgiler ışığında, bölüm mezunlarının özel eğitim hizmeti veren tüm kurum ve kuruluşlarda engelliler ile spor kapsamında çalışabilecekleri belirtilmiştir. Ek olarak, katılımcilar engellileri sporun bireysel ve toplumsal faydalarından yararlanarak rehabilite edebilecekleri de belirtilmiştir. Özel eğitime gereksinim duyan öğrencilere uygulanacak uygun eğitim programlarında, beden eğitimi ve spor uygulamalarının önemi sporun bireye kazandırdığ 1 nitelikler göz önüne alındığında, kendine yeten bir birey olarak yaşamın devamlılığını sağlama ve toplumsal uyum yönüyle ne kadar önem taşıdığı bilinmektedir (Milli Eğitim Bakanlı̆̆ı, 2012). Hatta günümüzde engelli bireyler, normal gelişim gösteren bireylerin yaptı̆̆ spor branşlarının birçoğunu başarıyla yapmaktadır (Tekkurşun-Demir, İlhan, Esentürk ve Kan, 2018). Sporun normal gelişim gösteren bireyler üzerinde yaptığı olumlu etkilerin tümünü ve hatta daha fazlasını engelli bireyler üzerinde de gözlemlemek mümkündür (İlhan, 2010).

Katılımcılar, alana hâkim uzmanlar yetiştirilmesi, engellilere kaliteli eğitim verilmesi, engellilere ve yakınlarına destek olunması ayrıca engelli sporcular için ihtiyaç duyulan bir bölüm olduğunu dile getirmişlerdir. Türkiye'de engelliler için Beden Eğitimi ve Spor öğretmeni 
yetiştirilmediğinden, beden eğitimi öğretmeni tüm engelli bireylerin beden eğitimi derslerine de girmektedir (Gürsel, 2006). Bu bölümün açılış gayelerinden önde gelenlerinden bir tanesinin de bu alandaki eksikliği gidermek olduğu ifade edilebilir. Öyle ki, İnönü Üniversitesi (2019) bu bölüm program yeterliliği altında, eğitim alacak kişiler için: 'Engelli bireylere yönelik spor eğitimi, egzersiz ve beden eğitimi alanlarındaki hizmet verme süreçleri ve işlemleri ile ilgili bilgiye sahiptir." ifadelerine yer vermektedir. Alana hâkim uzmanlar yetiştirilmesi görüşü, bölümün misyonunda belirtilen 'ülkemizin ihtiyaç duyduğu engelli sporu alanında yetişmiş insan gücünü ülkemize kazandırmayı amaç edinmiştir" ilkesiyle de örtüşmektedir.

Araştırmanın sonucu olarak, bu bölümde lisans eğitimi almış ve mezun olmuş öğrencilerin, çoğunluğun gerekli araştırmaları yaparak istihdam olanaklarından dolayı bu bölümde eğitim almayı tercih ettikleri fakat eğitime başladıktan sonra bölüm değişikliği düşündükleri ve lisans eğitimleri boyunca aldıkları derslerin kalitesiz olduğunu düşündükleri belirlenmiştir. Ayrıca katılımcıların, engellilere yönelik olan tutumlarının aldıkları eğitimle birlikte pozitif yönde değişimler gösterdiği ve engelli öğrencilere ayrılan kontenjanın artırılması gerekliliği bulgusu elde edilmiştir. Bir diğer bulgu olaraksa, Engellilerde Egzersiz ve Spor Eğitimi bölümünün özel eğitim bölümlerinden farklı olduğunu ve bu bölüm mezunlarının özel gereksinimli bireylerin bulunduğu kurumlarda istihdam edilmeleri gerekliliği bulunmuştur. Buna ek olarak, alana hâkim uzmanlar yetiştirilmesi, engellilere kaliteli eğitim verilebilmesi, engellilere ve yakınlarına destek olunması ve engelli sporcular için bölüme ihtiyaç duyulduğu tespit edilmiştir. Genel olarak araştırma bulguları incelendiğinde, bölümün misyonu, vizyonu ve program yeterlilikleri ile bulunan sonuçlar arasında benzerlikler ve farklılıklar tespit edilmiştir.

Araştırmada elde edilen bulgulara göre bölümün yeni açılmış olmasından ötürü eksikliklerinin olduğu gözlemlenmiştir. Bu bağlamda çeşitli öneriler geliştirilmiş̧tir.

1. TÜİK (2010) verilerine göre, lise ve daha üstü eğitim seviyelerinde engelli birey oranı 7.7'dir. Özellikle eğitim alanında engelli bireylere pozitif ayrımcılık yapılarak alanda daha çok yer almaları teşvik edilebilir.

2. Engellilere hizmet etmesi adına açılmış ve öncü olan 'Engellilerde Egzersiz ve Spor Eğitimi" bölümünün bilinirliliği yüksek ve daha merkezi bir konuma sahip üniversite bünyesinde kurulması sağlanabilir. Ya da bölümün bulunduğu bölgelerde özel eğitim alanlarına yatırımlar yapılarak öğrencileri teşvik edecek girişimlerde bulunulabilir. 
3. Mezunların eğitimlerine aynı alan da devam edebilmeleri ve kendilerini yetiştirebilmeleri adına lisansüstü eğitim programı açılabilir.

Yayın Etiği: Mevcut çalı̧̧manın yazım sürecinde "Yükseköğretim Kurumları Bilimsel Araştırma

ve Yayın Etiği Yönergesi” kapsamında bilimsel, etik ve alıntı kurallarına uyulmuş olup; toplanan veriler üzerinde herhangi bir tahrifat yapılmamış ve bu çalışma herhangi başka bir akademik yayın ortamına değerlendirme için gönderilmemiştir.

\section{KAYNAKLAR}

Açak, M., Karakaya, Y.E., Tan, Ç., Coşkuner, Z. (2016). Engellilerde egzersiz ve spor eğitimi bölümü öğrencilerin engellilere yönelik tutumlarının incelenmesi, Turkish Studies, 11(19), 1-8.

Arslan C. (2014). Inönü Üniversitesi, Beden Eğitimi ve Spor Yüksekokulu, Engellilerde Spor Eğitimi Öğretmenliği Bölümü Kuruluş Dosyası, 2. Uluslararası Engellilerde Beden Eğitimi ve Spor Kongresi'nde sunulmuş bildiri, Batman Üniversitesi, Batman.

Avramidis E, Bayliss P, Burden R. (2000). A survey into mainstream teachers' attitudes towards the inclusion of children with special educational needs in the ordinary school in one local education authority. Educational Psychology, 20(2), 191211.

Burcu, E. (2013). Engelli gençlik ve sosyal riskler. Journal of Youth Research. 2, 30-45.

Eroğlu, Y. (2017). Engelliler ve spor. N. Mirzeoğlu (Ed.), Spor Bilimlerine Giriş. Ankara: Spor Yayınevi ve Kitap Evi.

Ersoy, A. F. (2016). Fenomenoloji. Eğitimde nitel araştırma desenleri. (Edt: A. Saban ve A. Ersoy). Ankara: Anı.

Gürsel, F. (2006) Engelliler için beden eğitimi ve spor dersinin öğrencilerin engellilere yönelik tutumlarına etkisi, Hacettepe Üniversitesi Eğitim Fakültesi Dergisi, 31, 67-73.

İhan, E.L. (2010). Hareketsiz yaşamlar kültürü ve beraberinde getirdikleri, Milli Prodüktivite Merkezi Verimlilik Dergisi, 195210.

İnönü Üniversitesi (2019). Program yeterlilikleri. http://inonu.edu.tr/tr/eeseb/10086/menu?m=11634 adresinden erişilmiştir.

Kabasakal, K. (2007). Zihinsel engellilik, zihinsel, ruhsal, duygusal engellilik. Konya: Lokomotif Medya.

Karasar, N. (2015). Bilimsel araştırma yöntemi. Ankara: Nobel Yayınları.

Kınalı, G. (2003). Zihin engellilerde beden-resim-müzik eğitimi, farklı gelişen çocuklar, (Ed: Kulaksızoğlu, A.), İstanbul: Epsilon Yayınları.

Konar, N. \& Yıldıran, İ. (2012). Engelliler için beden eğitimi ve spor öğretmenliği: Gereksinim ve bir program modeli. Selçuk Universitesi Beden Eğitimi ve Spor Bilim Dergisi, 14(2), 208-216.

Koparan, Ş. (2013). Özel ihtiyaçları olan çocuklarda spor. Uludă̆ Üniversitesi Eğitim Fakültesi Dergisi, 17 (1), $153-160$.

Milli Eğitim Bakanlığı, (2012). Oyun ve fiziki etkinlikler dersi öğretim program (İlkokul 1-4. Sinıflar). Ankara: MEB.

Resmi Gazete (2005). Özürlüler ve bazı kanun ve kanun hükmünde kararnamelerde değişiklik yapılması hakkında kanun. http://www.resmigazete.gov.tr/eskiler/2005/07/20050707-2.htm adresinden erişilmiştir.

Sevim, Y. (2002). Antrenman bilgisi. Ankara: Nobel Yayınları. 
Can, H.C., ve İlhan, E.L. (2020). Mezun görüşleri bakımından engellilerde egzersiz ve spor eğitimi bölümünün profili. $C B \ddot{U}$ Beden Eğitimi ve Spor Bilimleri Dergisi, 15 (1), 2-17.

Tekkurşun-Demir, G., İlhan,E., L., Esentürk, O.,K., Kan, A. (2018). Engelli bireylerde spora katılım motivasyon ölçeği (ESKMÖ): Geçerlik ve güvenirlik çalışması. Spormetre, 16(1), 95-106.

Türkiye İstatistik Kurumu (2010). Türkiye engelliler araştırması. http://www.tuik.gov.tr/Start.do adresinden erişilmiştir.

Vural, M., Esentaş, M., Iş1kgöz, M.E. (2018). Engellilerde egzersiz ve spor eğitimi bölümü öğrencilerinin engellilere yönelik tutumlarının incelenmesi (İnönü Üniversitesi Örneği), CBÜ Beden Eğitimi ve Spor Bilimleri Dergisi, 13(1), 1-11.

Yazıcıoğlu, Y. \& Erdoğan, S. (2004). SPSS uygulamalı bilimsel araştırma yöntemleri. Ankara: Detay Yayıncılık.

Yıldırım, A. \& Şimşek, H. (2016). Sosyal bilimlerde nitel araştırma yöntemleri. Ankara: Seçkin Yayıncılık.

Yılmaz, T., Gökçe, D., Şavklı, F., \& Çeşmeci, S. (2012). Engellilerin üniversite kampüslerinde ortak mekanları kullanabilmeleri üzerine bir araştırma: Akdeniz Üniversitesi Olbia Kültür Merkezi örneği. JOTAF/Tekirdağ Ziraat Fakültesi Dergisi. 9(3), 1-10. 